\title{
Exploring the Business Planning Practices in Smes in a Developing Country
}

\author{
Andrea Ivanisević \\ Assistant Professor, University of Novi Sad, Faculty of Technical Sciences Novi Sad, Trg Dositeja Obradovića 6, \\ 21000 Novi Sad, Serbia. E-mail: andreai@uns.ac.rs

\section{Alpar Lošonc} \\ Full Professor, University of Novi Sad, Faculty of Technical Sciences Novi Sad, Trg Dositeja Obradovića 6, 21000 \\ Novi Sad, Serbia. E-mail: alpar@uns.ac.rs

\section{Slobodan Morača} \\ Assistant Professor, University of Novi Sad, Faculty of Technical Sciences Novi Sad, Trg Dositeja Obradovića 6, \\ 21000 Novi Sad, Serbia. E-mail: moraca@uns.ac.rs
}

\section{Petar Vrgović}

Assistant Professor, University of Novi Sad, Faculty of Technical Sciences Novi Sad, Trg Dositeja Obradovića 6, 21000 Novi Sad, Serbia. E-mail: vrgovic@uns.ac.rs

\section{Ivana Katić}

Assistant Professor, University of Novi Sad, Faculty of Technical Sciences Novi Sad, Trg Dositeja Obradovića 6, 21000 Novi Sad, Serbia. E-mail: ivana.katic.80@gmail.com

Received (28.12.2018.); Revised (21.01.2019.); Accepted (20.02.2019.)

\begin{abstract}
This paper analyzes the situation in the field of business planning in small and medium enterprises in Serbia, as well as the attitudes of managers towards a business planning system introduced in the enterprise. The aim of this paper is to determine whether the enterprises which have introduced such a planning system have it as a formal process, and if they do, is the implementation monitored throughout a year, and also, are any measures taken in case of deterioration of business and poor business results, in order to achieve more rational business i.e. is adequate monitoring applied in line with the feedback system?
\end{abstract}

Key words: business plan, control, environment, uncertainty, feedback.

\section{INTRODUCTION}

Literature gives opposing opinions regarding business planning and its impact on the operations of small and medium, already established, and new enterprises.

For a long time, it has been believed that successful decision making and planning process depend on a manager's talent and skills obtained during the age-long experience. Such approach is still present today in most of the small and medium enterprises which use individual styles and approaches in solving most of the managerial problems. Those approaches are primarily based on creativity, assessment capability, intuition, experience, and ability to make decisions fast with a minimum risk, and only after do they consider studious and thorough analyses shaped by some of the expert approaches.

However, even after fifty years of active analysis of the planning process, no agreement has been achieved in literature on the issue of impact of business planning on the achieved results. Both types of enterprises, new and small already existing enterprises, have different planning systems. Small, already existing enterprises have certain connections with the market and an already established business system. New enterprises have to decide on the organizational structure and processes, and they have to establish the connections with their environment. They do not have any information from earlier business operations. It is well known that, over the last fifteen years, the changes that have taken place in our environment have caused business conditions of production enterprises in Serbia to change completely. In that period, not only political but also the economic system in Serbia changed completely. The public property was transformed into private, collective management was replaced by modern management models, and planned economy was replaced by the market economy.

Those enterprises have planning as a process which is implemented more as a random or target element, without the possibility of adjustment made according to the feedback mechanism. The planning is done on the basis of intuition and individual decisions of a manager, most often the owner of the enterprise. In most cases, 
such decisions are not numerically quantified. The business plan is often created in the form of a budget, based on unreal expenses. In order to present and settle the income with expenses in the plan, the plan is devised in an unrealistic manner. Over the last few years, it has been proved that such production systems are very vulnerable to the changes.

\section{LITERATURE REVIEW}

There used to be a generally accepted attitude in literature by which the operations of the enterprise would be more successful with more formal, more organized approach to the planning process. Although small and medium-sized enterprises (SMEs) typically employ a major share of an economy's total employees, SME management suffers from an insufficient business-related knowledge base that top managers in SMEs posses. Formal plans are often only provided on an irregular basis and planning instruments are usually only by small number of individuals and developed rather intuitively (Brinkmann, 2002).

Literature offers two main movements which provide theoretical basis of business planning effects on operations success, the so called planning and learning (Wiltbank et al., 2006 and Brews and Hunt, 1999).

The movement focused on planning is based on the assumption that planning generally contributes to the achievement of bigger efficiency and easier goal reaching (Ansoff, 1991). Certain authors (Delmar and Shane, 2003) cluster various positive effects of planning. In case of any deviations from the plan, the causes of deviations can be identified and they have to be built into future planning (Ivanisevic, 2011). The supporters of the planning emphasize that significance of business planning is particularly expressed in dynamic and unstable environment because planning decreases the level of uncertainty, facilitates and accelerates the decision making process (Sarason and Tegarden, 2003).

The opposite approach, the so called learning school, supports the approach of adjustment to strategy development. Ever since some authors announced the downfall of that field, there has been increasing skepticism about the possibilities of business planning to create good strategies or make positive impact on company's business performances (Machado et al 2017).

This way, unplanned strategies give a chance to fast reaction, especially in unstable and unpredictable environments, in order not to miss any opportunities (Mosakowski, 1997, Mintzberg and Waters, 1985). Such attitude towards business planning further emphasizes that instead of spending time on predicting the future, the executives would benefit more from allocating the resources they are controlling at the moment and getting new resources (Honig, 2004).

However, some earlier studies about the results that companies achieved due to planning showed some positive effects (Schwenk and Shrader, 1993). In addition, new studies dealing with planning research suggest that planning has positive impact on business results (Gruber, 2007). As regards the business practice in the world, it seems that in the field of entrepreneurship there is a euphoria relating to planning and that there is a generally-adopted assumption that more business planning may lead to more successful business (Gartner and Liao, 2005).

In literature about business planning, there is a difference between the process of business planning which is continuously executed throughout the year, meaning the activities that are taken to develop the plans and outcomes of business planning, i.e. business plan in writing (Buchko, 1994). Some scientists have concluded that formal written business plans are more significant for the company's business success than continuous execution of business planning processes because the written documentation gives legitimacy to the company and enables better communication with internal and external environment. In addition, one may also find literature which emphasizes the significance of business planning process because it helps understanding the business itself and offers the possibility of learning (Lekovic et al, 2013).

In this respect, the validity of such attitudes is tested through work, through the prism of importance of planning processes for the enterprises in Serbia.

Building on a literature analysis, present research on business planning in SMEs is still in its infancy and insufficiently differentiated with respect to enterprise characteristics and from research into larger organizations. Business planning is the attempt to prepare for future contingencies and thus to account for environmental dynamics and complexity.

Although the future cannot be predicted, it is possible to prepare for the future and/or alternative futures and align enterprise accordingly. Business planning provides guidelines and programs for achievement of specific goals and visions. Many decision-makers in SMEs are convinced that the real enterpreneurs do not plan (Posner, 1985). Insrtead, it is assumed that they use their limited time resources more effectively for operational or sales activities. Formal planning is often regarded as limited to large enterprises and thus not transferable to the requirements of the fast moving and flexibly-structured SMEs.

Several empirical studies reveal a link between strategic planning and success:

- $\quad$ Gibson and Cassar,2002-more than 30\% of the enterprises apply documented planning, however only $50 \%$ of those on an annual basis. Bigger companies plan more than smaller ones. The higher the level of education, the more likely planning is.

- $\quad$ Leitner, 2001-Core competency planning is none of the examined enterprises. $88 \%$ develop strategies due to experience, $31 \%$ due to intuition.

- Kargar and Parnell, 1996-The advantages of strategic planning out weight the costs. To renounce strategic planning means to neglect a possible competetive advantage. Effective strategic planning can mean higher perfonmance.

- $\quad$ Gorman and Doran, 1999-Almost no long-term planning. Success depends on person.

- Lyles et al, 1993-Enterprises with formal planning have higher growth of turnover. Strategic 
decision-making varies strongly between formal and informal planners.

- $\quad$ Matthews and scott, 1995-Extent and type of planning depend on the status of the enterprise (enterpreneurial or traditional). The more uncertain the environment, the less planning is conducted.

This paper presents empirical results about the way the planning is conducted in small and medium enterprises in Serbia. Its goal is to show the conditions in the field of business planning in small and medium enterprises in Serbia, to identify the effective planning systems which actually give the best results in business, but also bad practice that needs to be avoided. In other words, besides the question whether the approach to business planning used so far is good for small and medium enterprises, the goal of this paper is, also, to find the empirical proof that the business plans show increased efficiency in business.

The well known fact is that the external environment of an enterprise (suppliers, clients etc.) but also the employees in the enterprise often want to see the business plan in order to assess the feasibility of the business and the degree of its attractiveness from the economic aspect (Hough and White, 2003). Such tendencies have been noticed and studied in literature by a few authors. It is not a surprise that the studies dealing with planning system analysis in companies where it is not a formal process find different business results when compared to the enterprises which are focused only on written documentation as a result of a business plan which is not monitored throughout the year. One of the basic, starting assumptions of this paper is that formal planning systems i.e. pro forma planning does not give the expected positive effects in business. This paper is an attempt to support such attitudes, through parallel assessment of the form and the purpose of planning process, as well as its further impact on business success (Lange et al, 2007).

The key arguments against applying the long-term and more complex planning models also show that planning can be a very expensive process. It often implies hiring extra staff, purchasing data bases, engaging consultants as well as engaging other company's resources (time and space for example) from current operational tasks. The lack of support to planning from the top management often results in rejection of plans (Lorange, 1980). This paper is also trying to find the answers to the questions whether there are enterprises which use already developed systems on the market, and at what extent they use those systems.

Having in mind the previously defined goal, the paper set up the following hypotheses:

Hypothesis 1. In small and medium enterprises, created in the first phase of transitional processes, which basically have not become stable firms, the planning system has a rather formal character.

Hypothesis 2. Planning system with a feedback which has already defined possible ways of correcting the business in cases of disturbed conditions or business results and their mathematical inter-dependence, still does not have appropriate place in the process of running the business policy in small and medium enterprises.

Hypothesis 3. Circumstances like uncertainty, limitations of structure and procedures for creating plans, and the attitude that best decisions are made on the basis of experience and intuition, create skepticism toward planning system (resistance).

\section{RESEARCH}

In this paper, the authors analyze the situation in the field of business planning in small and medium enterprises in Serbia, as well as the nature of managers' attitudes towards the business planning system in the enterprises it had been introduced in. The goal of this paper is to assess whether it is reasonable to introduce the planning system, if it is just a formal process, if it has been created is there any monitoring of its implementation throughout the year, and whether there are any measures taken in case of tendency towards deterioration of business conditions and poor business results in order to achieve more rational business i.e. if adequate control is applied in line with the feedback system.

The research comprised in the paper was executed on a representative sample of 153 enterprises from the category of small and medium enterprises (SMEs), where the data was collected in a way that one questionnaire had been filled out by the individual enterprise by persons responsible for business planning and analysis of current operations which are exactly the subject of this paper. The SMEs were all geographically located in the Autonomous Province of Vojvodina, the northern and most economically developed part of the Republic of Serbia. The SMEs in this sample were contacted through a study project realized by the students of the University of Novi Sad, within educational activities that are part of the Engineering Management curriculum. The sample consisted of SMEs from all relevant activity groups in this Province, with equal distribution of the major groups performing different activities: trading, manufacturing, logistics \& transportation, agricultural, services and hightechnology. Since the companies were contacted in an unconventional way (directly on-the-spot by the students, and not by surface mail or by e-mail), the response rate was quite high, with slightly more than half of the contacted enterprises being willing to participate in this research. Nevertheless, no significant bias was identified for the data collectors or the data providers in the initial screening of the received data, nor there was any significant difference between early respondents and late respondents. Companies in the sample had a median of being 8 years old.

\section{METHODOLOGY}

In order to test the hypotheses, a survey research was performed on the sample of small and medium enterprises as well as work organizations on the territory of the Republic of Serbia. A questionnaire consisting of relevant questions of closed type was 
created and the questions were clustered in 5 groups (questions used in this research are presented in Appendix $A$, the complete questionnaire may be obtained from the authors):

1. Approach to planning - one-year business plan for the enterprise. This cluster of questions follows basic steps in one-year planning from the standpoint of the whole organization like the planning fact, details about plan acceptance, impact of the plan on business.

2. Planning processes. This cluster of questions refers to the way the plan is implemented, its range and the coverage of organizational aspects.

3. Monitoring of business plan realization. This segment of the questionnaire describes in detail the ways of checking and monitoring the execution of plans, as well as their modifications, if needed.

4. Specific questions relating to planning. These questions analyze the impact of the organizational reaction plan on external hindrances, as well as the impact such hindrances have on the realization of the set plan.

5. Resistance to planning. This segment considers the frequencies and structure of resistance to changes, as well as the most common reasons for their occurrence.

The questionnaire was successfully completed in 153 private enterprises and organizations. The entered data were processed in software SPSS V20, using basic methods of descriptive statistics. Because of the nonparametric nature of the data obtained in this research, Spearman Correlation, as well as Crosstabs procedure with Cramer's $\mathrm{V}$ coefficient of significance was used for identifying the connection between the variables.

\section{RESULTS}

Hypothesis 1. implies that enterprises have planning systems that probably have a strict form, but low level of application and impact. Figure 1 shows that $62 \%$ of the sample enterprises perceive their business plans as more than just a formality, which implies that their business plan will have some direct effect on the business processes.

\section{Is the created business plan just a formal document?}

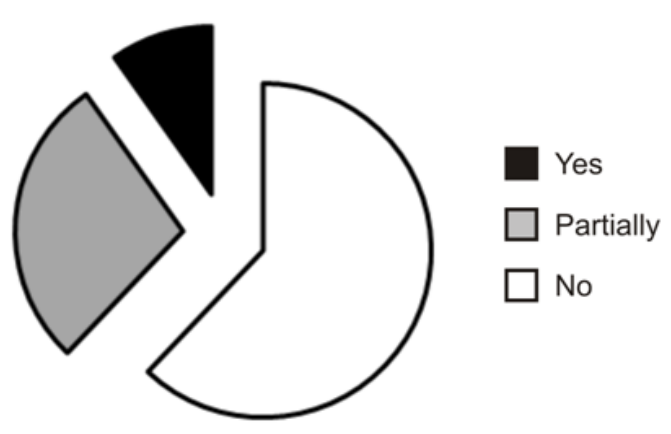

Figure 1. Level of business plan application and significance Source: Research results
Furthermore, formality can be observed as absence of full impact on the current processes. In other words, business plan that has limited impact on enterprise's reality should be considered as a formal statement without practical significance.

Figure 2 illustrates that almost half of the enterprises from the sample have business plans that have only limited impact on current processes. This shows that there is a significant number of SMEs that have business plans with limited impact

\section{Does the accepted plan have any impact on} current operations?

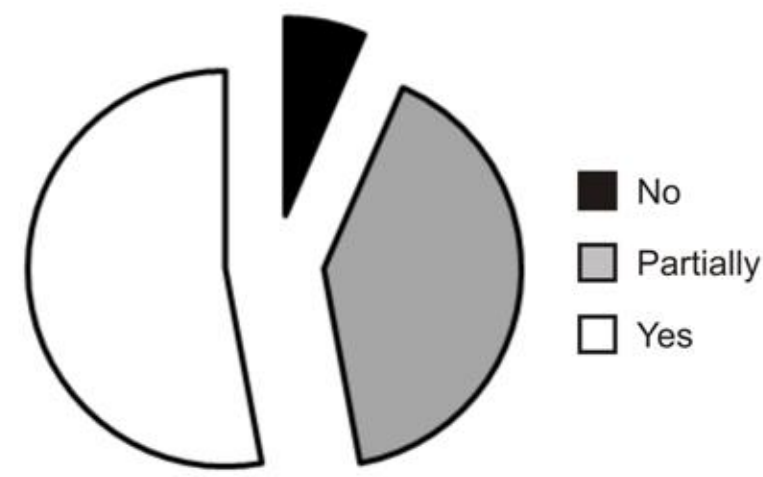

Figure 2. Perceived impact of the business plan Source: Research results

Importance of the planning process may be measured by the strictness of its creation procedure. If the planning process has a well-defined start, it may suggest that the enterprise perceives that plan as important and that it will probably be implemented. Figure 3 shows that slightly more than half of the enterprises have appropriate procedures for creating business plans, while $43 \%$ state that their procedures are insufficient, which endangers the business plan from its beginning and may lead to "just a formality" status of that plan.

\section{Are there written procedures for creating the business plan?}

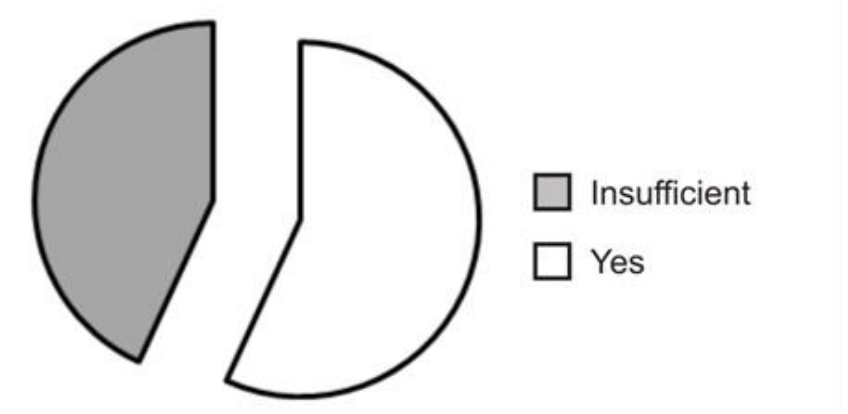

Figure 3. Availability of business plan creation procedures Source: Research results 
The relationship between the status that a business plan has in the work organization (are they just formal documents or they have a certain usage value) and the impact of such a plan on current operations in the organization has been observed. The frequencies of answers to these two questions were compared by crosstabs function (Table 1), and they showed that most organizations for which the business plan was more than just a formal document identified that such plan had impact on business operations. A significant and moderately negative correlation in statistical terms (Spearman's Rho =$.442, p=.00$ ) was determined for the listed questions, which means that the plans treated as "usable" often really have impact on current operations.

Table 1. Crosstabulation of companies' formalization of business plan and impact of the plan on current operations

\begin{tabular}{|c|c|c|c|c|c|}
\hline & \multicolumn{3}{|c|}{$\begin{array}{l}\text { Does the accepted } \\
\text { plan have any } \\
\text { impact on current } \\
\text { operations? }\end{array}$} & \multirow[t]{2}{*}{ Total } \\
\hline & & yes & partially & no & \\
\hline \multirow{3}{*}{$\begin{array}{l}\text { Is the } \\
\text { created } \\
\text { business } \\
\text { plan just a } \\
\text { formal } \\
\text { document? }\end{array}$} & yes & 5 & 10 & 0 & 15 \\
\hline & partially & 8 & 28 & 7 & 43 \\
\hline & no & 68 & 24 & 3 & 95 \\
\hline \multicolumn{2}{|l|}{ Total } & 81 & 62 & 10 & 153 \\
\hline
\end{tabular}

After viewing the relationship between the subjects responsible for preparation of the business plans and subjects responsible for accepting such plans, the results showed that the organizations which have a special unit for planning have their board of directors entrusted with the responsibility for adoption of such a plan. In contrast to them, the organizations where a chosen person is responsible for preparation of the plans, in the vast majority of cases, the owner is the person who adopts the created plan (Table 2).

Table 2. Crosstabulation of bodies responsible for composing and adopting plans

\section{Count}

\begin{tabular}{|c|c|c|c|c|c|}
\hline & \multicolumn{3}{|c|}{$\begin{array}{l}\text { Which body adopts the } \\
\text { business plan? }\end{array}$} & \multirow[b]{2}{*}{ Total } \\
\hline & & Owner & $\begin{array}{l}\text { Board of } \\
\text { Director } \\
\text { s }\end{array}$ & $\begin{array}{l}\text { CFO } \\
\text { or } \\
\text { others }\end{array}$ & \\
\hline \multirow{4}{*}{$\begin{array}{l}\text { Who is } \\
\text { responsib } \\
\text { le for } \\
\text { composin } \\
\text { g annual } \\
\text { business } \\
\text { plans }\end{array}$} & $\begin{array}{l}\text { Planning } \\
\text { Unit }\end{array}$ & 10 & 20 & 4 & 34 \\
\hline & $\begin{array}{l}\text { Specific } \\
\text { person }\end{array}$ & 60 & 17 & 7 & 84 \\
\hline & $\begin{array}{l}\text { Main } \\
\text { office }\end{array}$ & 5 & 5 & 0 & 10 \\
\hline & $\begin{array}{l}\text { Somebod } \\
\text { y else }\end{array}$ & 16 & 5 & 4 & 25 \\
\hline \multicolumn{2}{|l|}{ Total } & 91 & 47 & 15 & 153 \\
\hline
\end{tabular}

There is a moderately high statistically significant correlation between these variables (Cramer's V $=.278, p=.00$ ), which means that there is a pattern in the relationship between subjects responsible for preparation of business plans and those responsible for their adoption.

Furthermore, in order to prove or deny the first hypothesis, the relationship between the existence of clear and complete procedure for preparation of business plans, and the subject which approves such business plan were analyzed.

The frequencies of answers to these questions were compared by crosstabs function, which is presented in Table 3, and they showed that in organizations where boards of directors approved the business plan, the percentage of appropriate written procedures for preparation of business plans was the highest. In contrast to them, with those where business plans were approved by the owner or some third person, there was more than half of those who assessed their written procedures for preparation of business plans as insufficient.

A statistically significant correlation was determined to be moderately high (Cramer's $V=.265, p=.00$ ) for these questions, which means that there is a significant correlation between the degree of formalization in creation of the business plan and the body (person) which/who approves such a plan.

Table 3. Crosstabulation of approving subjects and formalization of business plan

\begin{tabular}{|c|c|c|c|c|}
\hline \multicolumn{5}{|l|}{ Count } \\
\hline & & \multicolumn{2}{|c|}{$\begin{array}{l}\text { Are there written } \\
\text { procedures for } \\
\text { business plan } \\
\text { creation? }\end{array}$} & \multirow[t]{2}{*}{ Total } \\
\hline & & yes & insufficient & \\
\hline \multirow{3}{*}{$\begin{array}{l}\text { Which body } \\
\text { approves of } \\
\text { the business } \\
\text { plan }\end{array}$} & Owner & 44 & 47 & 91 \\
\hline & $\begin{array}{l}\text { Board of } \\
\text { Directors }\end{array}$ & 36 & 11 & 47 \\
\hline & $\begin{array}{l}\text { CFO or } \\
\text { others }\end{array}$ & 7 & 8 & 15 \\
\hline \multicolumn{2}{|l|}{ Total } & 87 & 66 & 153 \\
\hline
\end{tabular}

The analysis of the second hypothesis shows that the scope of implementation and control of the plan, and particularly the degree of impact of the planning system on the ongoing operations were also observed (the existence of feedback mechanism and other) in Tables 4 and 5. By comparing the listed questions, we obtained the statistically significant difference, which means that there is a correlation between these two variables. This is graphically presented in Figure 4 where the control of plan implementation is of a general character; the largest number of enterprises does not show resistance against plan changes during the year; the control of plan implementation is very thorough, and the number of enterprises with recorded resistance to plan changes in the current year is growing. 
Table 4. Crosstabulation of monitoring of the plan implementation and resistance to plan changes Crosstab

\begin{tabular}{|c|c|c|c|c|}
\hline \multicolumn{5}{|l|}{ Count } \\
\hline & & \multicolumn{2}{|c|}{$\begin{array}{l}\text { Is there any } \\
\text { resistance to the } \\
\text { plan changes in } \\
\text { the current year? }\end{array}$} & \multirow[t]{2}{*}{ Total } \\
\hline & & $\begin{array}{l}\text { Yes, at } \\
\text { least } \\
\text { partially }\end{array}$ & No & \\
\hline \multirow{3}{*}{$\begin{array}{l}\text { Is there } \\
\text { monitoring of } \\
\text { plan } \\
\text { implementatio } \\
n ?\end{array}$} & $\begin{array}{l}\text { Yes, } \\
\text { general }\end{array}$ & 14 & 71 & 85 \\
\hline & $\begin{array}{l}\text { Yes, in } \\
\text { details }\end{array}$ & 25 & 33 & 58 \\
\hline & No & 3 & 44 & 7 \\
\hline \multicolumn{2}{|l|}{ Total } & 42 & 108 & 150 \\
\hline
\end{tabular}

Table 5. Crosstabulation significance

\begin{tabular}{|l|l|l|l|}
\hline & Value & df & $\begin{array}{l}\text { Asymp. Sing. } \\
\text { (2-sided) }\end{array}$ \\
\hline $\begin{array}{l}\text { Pearson Chi- } \\
\text { Square }\end{array}$ & $12.934^{\mathrm{a}}$ & 2 & .002 \\
\hline $\begin{array}{l}\text { Likelihood } \\
\text { Ratio }\end{array}$ & 12.971 & 2 & .002 \\
\hline $\begin{array}{l}\text { Linear. By- } \\
\text { Linear } \\
\text { Association }\end{array}$ & 11.255 & 1 & .001 \\
\hline $\begin{array}{l}\text { N of Valid } \\
\text { Cases }\end{array}$ & 150 & & \\
\hline
\end{tabular}

a. 1 cells $(16.7 \%)$ have expected count less than 5 . The minimum expected count is 1.96 .

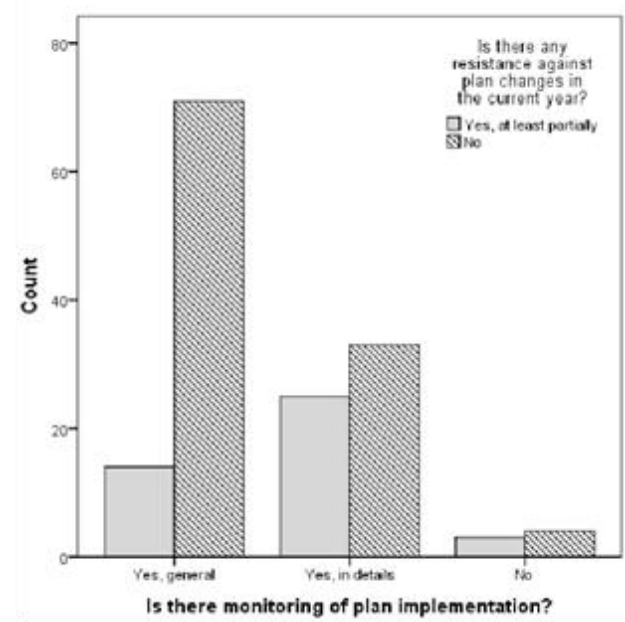

Figure 4. Distribution of monitoring of plan implementation and resistance to plan changes Source: Research results

Hypothesis 3 was first tested by comparing questions: "Were there any significant and unplanned problems in enterprise's business in the last two years?" and "Is there any resistance to the planning process by those who are supposed to make plans? "This way, we obtained a statistically significant difference (Tables 6 and 7 ), which means that there is a correlation between these two variables and it can be clearly seen in the graph below (Figure 5).

If there are some significant and unplanned hindrances in enterprise's business, the percentage of those who show resistance to the planning process is higher.
Table 6. Crosstabulation of business plan hindrances and resistance to plan changes

Count

\begin{tabular}{|l|l|l|l|l|}
\hline \multicolumn{1}{|l|}{} & \multicolumn{2}{|l|}{$\begin{array}{l}\text { Is there any resistance } \\
\text { to the planning process } \\
\text { by those who are } \\
\text { supposed to make } \\
\text { plans? }\end{array}$} & Total \\
\cline { 2 - 4 } & $\begin{array}{l}\text { Yes, at } \\
\text { least } \\
\text { partially }\end{array}$ & no & \\
\hline $\begin{array}{l}\text { Were there any } \\
\text { significant and } \\
\text { unplanned hindrances } \\
\text { in company's } \\
\text { business in the last } \\
\text { two years? }\end{array}$ & no & 20 & 49 & 69 \\
\hline Total & 11 & 71 & 82 \\
\hline
\end{tabular}

Table 7. Chi-Square Tests

\begin{tabular}{|l|l|l|l|l|l|}
\hline & Value & df & $\begin{array}{l}\text { Asymp. } \\
\text { Sig. (2- } \\
\text { sided) }\end{array}$ & $\begin{array}{l}\text { Exact } \\
\text { Sig. (2- } \\
\text { sided) }\end{array}$ & $\begin{array}{l}\text { Exact } \\
\text { Sig. (1- } \\
\text { sided) }\end{array}$ \\
\hline $\begin{array}{l}\text { Pearson Chi- } \\
\text { Square }\end{array}$ & $5.568^{\mathrm{a}}$ & 1 & .018 & & \\
\hline $\begin{array}{l}\text { Continuity } \\
\text { Correction }\end{array}$ & 4.655 & 1 & .031 & & \\
\hline $\begin{array}{l}\text { Likelihood } \\
\text { Ratio }\end{array}$ & 5.587 & 1 & .018 & & \\
\hline $\begin{array}{l}\text { Fisher's Exact } \\
\text { Test }\end{array}$ & & & & .025 & .015 \\
\hline $\begin{array}{l}\text { Linear-by- } \\
\text { Linear } \\
\text { Association }\end{array}$ & 5.531 & 1 & .019 & & \\
\hline $\begin{array}{l}\text { N of Valid } \\
\text { Cases }\end{array}$ & 151 & & & & \\
\hline $\begin{array}{l}\text { a. O cells (0.0\%) have expected count less than 5. The } \\
\text { minimum expected count is 14.17. } \\
\text { b. Computed only for a 2x2 table }\end{array}$ \\
\hline
\end{tabular}

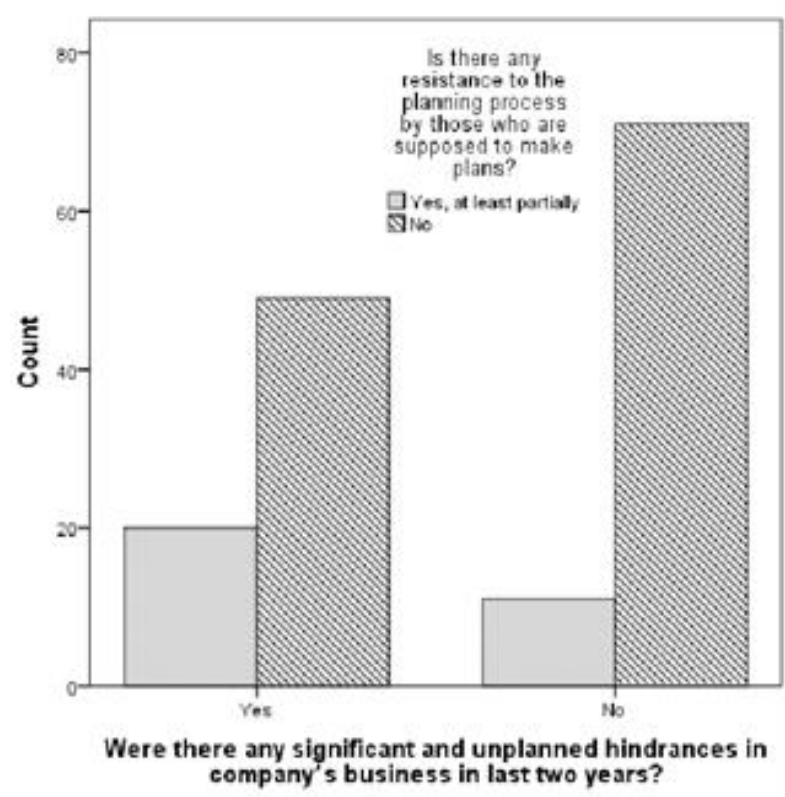

Figure 5. Distribution of hindrances and employee resistance Source: Research results

The frequency of answers to the question 'What are the most significant guidelines in creating a business plan?' were also observed. One may see that the largest number of organizations relies on realistic assessment 
of possibilities when writing a business plan, and to a similar extent organizations also rely on business details from the previous year. Other companies from the same industry are presented at the bottom of the list of relevant guidelines (Table 8).

Table 8. Most significant guidelines in creating a business plan

\begin{tabular}{|l|l|l|}
\hline $\begin{array}{l}\text { What are the } \\
\text { most significant } \\
\text { guidelines in } \\
\text { creating a } \\
\text { business plan? }\end{array}$ & $\begin{array}{l}\text { Number of } \\
\text { organizations } \\
\text { using this } \\
\text { guideline }\end{array}$ & $\begin{array}{l}\text { Percentage of } \\
\text { organizations } \\
\text { using this } \\
\text { guideline }\end{array}$ \\
\hline $\begin{array}{l}\text { Realistic } \\
\text { assessment of } \\
\text { possibilities }\end{array}$ & 113 & $73.9 \%$ \\
\hline $\begin{array}{l}\text { Operations from } \\
\text { the previous } \\
\text { year }\end{array}$ & 106 & $69.3 \%$ \\
\hline $\begin{array}{l}\text { Ahead defined } \\
\text { goals - wishes }\end{array}$ & 77 & $50.3 \%$ \\
\hline $\begin{array}{l}\text { General } \\
\text { economic } \\
\text { process in the } \\
\text { surroundings }\end{array}$ & 68 & $44.4 \%$ \\
\hline $\begin{array}{l}\text { Other } \\
\text { companies in } \\
\text { the same } \\
\text { industry }\end{array}$ & 32 & $20.9 \%$ \\
\hline
\end{tabular}

When we observe the use of computer programs for writing plans that already exist on the market, the results show that they are mostly supported by appropriate written procedures for writing business plans, in contrast to organizations that do not use such programs and half of those organizations have well written procedures for creating plans (Table 9). The results are also presented graphically in Figure 6 .

There is moderate, high statistically significant correlation between these variables (Cramer's V =.299, $\mathrm{p}=.00$ ) which can probably be explained by emphasizing the use of the procedure by software which has already been used.

Table 9. Crosstabulation of planning software usage and formalization of business plan

\begin{tabular}{|c|c|c|c|c|}
\hline & \multicolumn{2}{|c|}{$\begin{array}{l}\text { Are there written } \\
\text { procedures for creating } \\
\text { the business plan? }\end{array}$} & \multirow[t]{2}{*}{ Total } \\
\hline & & yes & insufficient & \\
\hline \multirow{2}{*}{$\begin{array}{l}\text { Do you use any of } \\
\text { the computer } \\
\text { programs that } \\
\text { already exist on the } \\
\text { market for writing } \\
\text { the business plan? }\end{array}$} & yes & 34 & 8 & 42 \\
\hline & 10 & 53 & 58 & 111 \\
\hline \multicolumn{2}{|l|}{ Total } & 87 & 66 & 153 \\
\hline
\end{tabular}

Do you use any of the computer programs that already exist on the market for writing business plans?

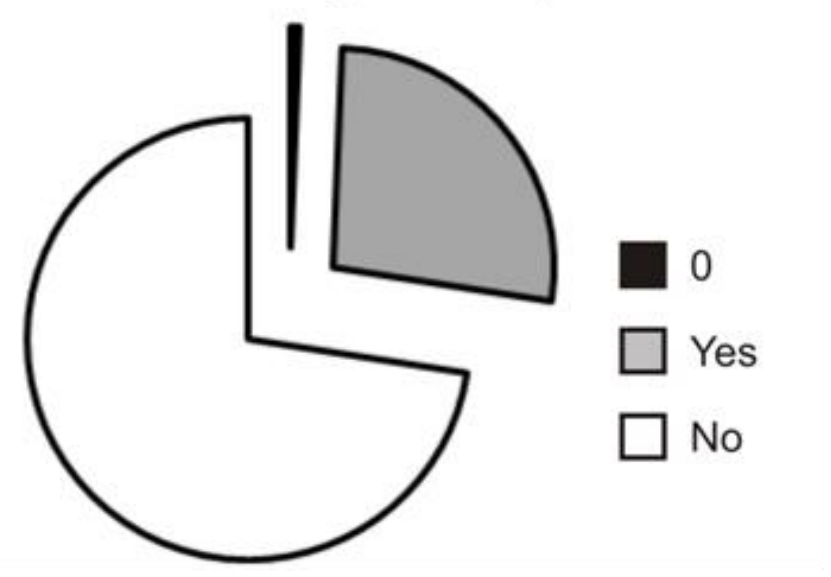

Figure 6. Planning software usage distribution Source: Research results

\section{DISCUSSION}

The results (research) presented in this paper represent contribution to the theory and practice of a company's business, providing insight into new relevant questions which cast light on the unexplored aspects of business planning. The results showed that the planning had impact on the ongoing operations and achievement of better performances (gaining profit) even in case of uncertainty and limited information which was discovered in the large number of companies in this research. By comparing these results with the results of previous studies which confirmed these opinions, it can be concluded that these results are significant, which has partly contributed to denying the attitudes of the socalled learning school. Based on this finding, it can also be concluded that the real value of planning for the ongoing business operations is visible only in case the plans are not just a formality.

Since business plans are mainly used declaratively in everyday business dictionary, this paper provides insight into real and not just formally recorded use of business plans in current operations of small and medium enterprises in Serbia.

The contributions of work are further considered in detail through discussion of results by using a few selected units which are used for proving the made hypotheses.

Firstly, the research presented in this paper provides important empirical evidence for managers' opinions relating to possible impact of plans on current operations. This has directly led to the question: Is there only a pro forma planning system or is it a tool which enables a manager to notice elements which are to be adjusted in current operations.

It is generally accepted that there is a positive relation between business planning and business performances. However, empirical research about the level of impact and application of business plans on current operations is stated in literature only in 
fragments and declaratively. By integrating previous studies and analyzing the results obtained in the research, this paper shows that, in practice, there are planning systems which are formal in character and which are not carried out based on the feedback system, and also the informal systems of planning which are based on experience, intuition and manager's abilities of assessment which do not have real value for current operations of companies.

This paper shows the importance of the research about the degree of realistic use of plans in business and not just their formal presence in written procedures i.e. documentation. These attitudes are confirmed by the results according to which the majority of respondents included in this research confirmed that annual business plans were regularly created (96.7\%). If conclusions are to be made just on these responses, the question of quality and content cannot be answered. On the other hand, if conclusions are to be made based on the results in percentage, it can be seen that companies in Serbia have been organized in a modern way with planned business. Furthermore, it is obvious that this is not the case in Serbia, especially in small and medium enterprises where the role of the owner is crucial when making decisions. It is also obvious that the criteria for making decisions, particularly the momentous ones, are based on intuition and without long term operating visions.

The basic aim of this paper, which relates to the question whether business plans exist only as pro forma plans (basic relation between plan and system of business), provided insight into expected findings and making the hypothesis.

Results in this paper clearly indicate to the fact that existence of written plans in companies is not directly connected with the companies' success because planning system, which is formal in character, does not have a significant impact on operations of the company. Furthermore, research presented in this paper reveals new contextual determinants of planning, which further raises doubt about frequently mentioned attitude in literature according to which the planning does not necessarily have to be a formal process at the beginning of one company's work. Therefore, written plans are considered to be less significant. Results obtained from the research imply that planning is equally important for and equally affects the operations of companies which have been working for a long period of time and small enterprises where most decisions are made by a manager i.e. company's owner, in which case lack of written plans indicates to the lack of positive business performances.

By observing the relationship between the subjects responsible for preparation of business plans and subjects who are responsible for accepting those plans, statistical analysis confirmed that there was a significant correlation between a person who created and accepted the plan and the degree of formalization in creation of this plan. This is a proof to the first hypothesis presented in this paper. Generally, results show that there is an adequate correlation (relationship) between clear and complete procedures for preparation of the business plan and the subject who is responsible for acceptance of the business plan.

These results additionally support the first hypothesis, and together with the previous results, they confirm the hypothesis which was first made in this paper.

Secondly, the results of the research presented in this paper show that only some deviations from limitations set by the plan are registered; therefore, the ongoing operations have to be adjusted in accordance with those deviations. Although the majority of respondents answered that realization of plan was analyzed throughout the year, almost half of them emphasized that these deviations were recorded only partially and used for adjustment of business. A time period of conducting these procedures, which were mostly carried out formally and in the period of two to three months as stated, was long. Monitoring of business operations was also carried out but, according to the results, it was done only formally. A degree of flexibility of planning process was depicted by the data according to which planning is flexible to some extent and is subjected to changes during the period of plan validity and in accordance with major changes which obstruct current operations.

By observing the scope of implementation and monitoring of plan execution, and particularly the degree of impact of planning system on current business (feedback mechanism and other), it can be concluded that there is a direct relation between monitoring of plan execution and resistance to the changes of the plan.

This confirmed the second set hypothesis in this paper. Thirdly, since it was determined that planning systems, which are formal in character, were not important for current operations, empirical findings supported the statement that companies had to adjust their planning systems based on the feedback mechanism, particularly in case of unstable business conditions.

The majority of respondents confirmed the initial assumption in this paper that tendencies in general economic situation have considerable impact on preparation of plans and often express skepticism towards the value of the created plans. This is why it is believed that the best decisions are made based on experience and intuition.

When asked to assess the resistance to planning process, a large number of respondents shared the opinion that planning lost its purpose in unstable political and economic conditions.

By supporting the opinion that environment has impact on the relation between planning and current operations, the results of this paper confirmed the third hypothesis.

The frequencies of answers to the question 'What are the most significant guidelines in creating a business plan?' were also observed. It can be noticed that the largest number of organizations relies on realistic assessment of possibilities when writing a business plan, and to a similar extent organizations also rely on business details from the previous year. Other companies from the same industry are presented at the bottom of the list of relevant guidelines, which can 
indicate to low influence of competition on business planning of an organization. Not only do these findings confirm the third hypothesis, but they also confirm the first one because it is clear that realistic assessment of possibilities is the reflection of random planning process and that uncertainty in the environment is the result of impossibility to use general economic processes as guidelines for business plan preparation.

Lack of knowledge is the second most mentioned reason for resistance to planning by respondents.

Therefore, results support the opinions that lack of structure and procedure for business plans create skepticism toward planning system (resistance).

Results of the research on the use of computer programs which have already been present on the market, for business plan preparation, and the fact that they are mostly supported by adequate written procedures for business plan preparation, unlike the organizations which do not use those programs where the number of those who have well-written procedures for business plan preparation indicate to the following conclusion:

In companies included in the research, it was obvious that the owner i.e. manager of a company was not interested in accepting this type of modern planning system because they did not allow planning to be performed based on the system but based on its operating visions.

\section{CONCLUSION}

This paper first shows the arguments illustrated by supporters of the learning and planning schools and then the empirical results obtained by the research so that basic relation between business plans and planning system in small and medium enterprises in Serbia could be analyzed.

After examining the planning systems that are used by enterprises in the domestic market, it is clear that they generally do not give the expected results. It can be carried out very general conclusion that surveyed the small and medium enterprises business planning a formal process, whether it is during the year does not control execution. Of course, that this conclusion can not be made and apply to all SMEs, but it is indisputable that indicate the general view of the inadequate evaluation of progress in business resulting from the planning system. It is completely incomprehensible to the disproportion in terms of need and expected in large production systems, parts of large foreign companies and small manufacturing system.

The intention of the authors of this work was to survey the fort mechanisms and models of planning processes of small and medium enterprises, or as a final result with the majority of the surveyed companies is established formal approach that is in some way confirmed the pre-defined views are following research objectives, and in the work of the proposed hypotheses. The most commonly used system planning is a process that is not organically connected with mehaniozmom business, he realized once at the beginning of the fiscal year.

By observing the planning systems that are applied in companies on national market, it can be seen that they do not give the expected results. The relationship between the management in small and medium enterprises was analyzed based on business planning systems. Although it is evident that business plans were mostly implemented in large number of companies presented in the research, the results of the research show that they were only prepared as pro forma plans. Arguments that support this opinion indicate that the scope of implementation and monitoring of plan execution and particularly the degree of impact of the planning system on current operations are clearly low. Therefore, it can be concluded that business planning as a formal process is carried out, but not controlled during a year.

Although it is completely clear that unique system of planning as universal and comprehensive for all companies throughout the history did not exist in the past, not even in times when planning was obligatory (socialism) and that there has always been a difference in planning systems, it can be concluded that preparation of plans with the only reason to meet the formality does not give to expected results. The author's intention here was not to analyze the plans as formal processes in planning systems but to provide insight into right attitude of companies' management towards this process.

It is also evident that it is not easy to develop a type of planning system which will not have to be implemented by a company, but to direct the company's process of decision-making. This should be a flexible planning system which will follow the logic of thinking i.e. attitude of company's management, thus offering companies independency in decision making and flexibility and ability of risk taking. However, it should rest on generally accepted business philosophy in the world profit maximization.

During preparation, we analyzed the results which were achieved in the field of business planning and use of results in practice.

The results considerably supported previously adopted attitudes which are in compliance with the aim of the research and hypotheses made in this paper. Based on the research planning system operating in small and medium-sized enterprises and the views of the author on this issue can bring a larger number of conclusions, including its:

1. It is not developed awareness of the need for business planning - what, as well as the development of the company are carried out spontaneously, and most often in the context of understanding and business scope of the company's owner.

2. The system of formal business planning presents an additional source of energy loss and confusion in the system business, and would, as such, should be completely eliminated from the process operations. 
3. Planning as a segment of the overall system is the framework for business operations, which in the course of the financial year is adjusted continuously analyzed with the terms of business, but not for a mechanism to satisfy forms, but in order to achieve better business results. It must be flexible and be a mechanism of business planning.

\section{ACKNOWLEDGEMENT}

This paper resulted from the Project 179052, entitled "The Transformation of Social Identity in Crisis Conditions and Its Impact on European Integration". The Project was funded by the Ministry of Education, Science and Technological Development of Serbia.

\section{REFERENCES}

[1] Ansoff, H.I., (1991), "Critique of Henry Mintzberg's The design school: reconsidering the basic premises of strategic planning", Strategic Management Journal, Vol. 12, No.6, pp. 449-46.

[2] Brews, P.J., Hunt M.R., (1999), "Learning to plan and planning to learn: resolving the planning school/learning school debate", Strategic Management Journal, Vol. 20 No. 10, pp. 889-913

[3] Brinkmann, M. (2002) Strategieentwicklung für kleine und mittlere Unternehmen, Zurich: Orell Füssli.

[4] Buchko, A., (1994), "Conceptualization and measurement of environmental uncertainty: an assessment of the miles and snow perceived environmental uncertainty scale", Academy of Management Journal, Vol.37, No. 2, pp. 410-25.

[5] Delmar, F., Shane, S., (2003), "Does business planning facilitate the development of new ventures?", Strategic Management Journal, Vol. 24 No. 12, pp. 1165-1185.

[6] Gartner, W.B., Liao, J., (2005), "Cents and Sense Making in Preventure Business Planning: Evidence from the Panel Study of Entrepreneurial Dynamics“, Frontiers of Entrepreneurship Research, Babson College, Wellesley, MA.

[7] Gibson, B., \& Cassar, G. (2002), "Planning behavior variables in small firms", Journal of Small Business Management, Vol. 40, No. 3, pp. 171-186.

[8] Gruber, M., (2007), "Uncovering the value of planning in new venture creation: a process and contingency perspective", Journal of Business Venturing, Vol. 22, No. 6, pp. 782-807.

[9] Hough, J. R., White, M. A., (2003), "Environmental dynamism and strategic decision-making rationality: an examination at the decision level', Strategic Management Journal, Vol. 24, No. 5, pp. $481-489$.

[10] Honig, B. (2004), "Entrepreneurship education: toward a model of contingency-based business planning", Academy of Management Learning \& Education, Vol. 3, No. 3, pp. 258-273.

[11] Ivanišević, A., Leković, B., Ćosić, I., Marić, B., Ćirić, J. (2011), "Principles of Business Systems Design with a Feedback in the Function of an Environmental Impact Plan and Set Goals", XV International Conference of Industrial Systems, pp. 396-399.

[12] Küpper, H.-U., \& Bronner, T. (1995), Strategische Ausrichtung mittelständischer Unternehmungen, Internationales
Gewerbearchiv, 43, pp. 73-87

[13] Lange, J.E., Mollov, A., Pearlmutter, M., Singh, S., Bygrave, W.D. (2007), "Pre-start-up formal business plans and post-startup performance: a study of 116 new ventures", Venture Capital, Vol. 9, No. 4, pp. 237-256.

[14] Leitner, K. H. (2001), Strategisches Verhalten von kleinen und mittleren Unternehmungen. Eine empirische Untersuchung an österreichischen Industrieunternehmen vor einem industrieökonomischen und organisationstheoretischen Hintergrund. Unpublished doctoral dissertation, University of Vienna, Austria.

[15] Leković, B., Ivanišević, A., Marić, B., Demko-Rihter, J., (2013), "Assessment of the most significant impacts of environment on the changes in company cost structure", Economic Research, Vol. 26, No.1, pp. 225-242

[16] Lorange, P., (1980), "Corporate Planning An Executive Viewpoint", Englewood Cliffs, NJ: Prentice Hall

[17] Lyles, M. A., Baird, I. S., Orris, J. B., \& Kuratko, D. F. (1993) Formalized planning in small business: Increasing strategic choices, Journal of Small Business Management, Vol. 31, No. 2, pp. 38-50.

[18] Machado, N.S., Roman, D.H. Ziger, R., Ficagna F, (2017), Application of Strategic Planning Methodology in Seven Brazilian Preincubated Enterprises in a Technological Innovation Center, International Journal of Industrial Engineering and Management (TIC), Vol. 8, No. 1, pp. 9-19.

[19] Matthews, C. H., \& Scott, S. G. (1995), "Uncertainty and planning in small and entrepreneurial firms: An empirical assessment", Journal of Small Business Management, Vol. 33, No. 4, pp. 34-52.

[20] Mintzberg, H., Waters, J.A., (1985), "Of strategies, deliberate and emergent", Strategic Management Journal, Vol. 6 No. 3, pp. 257-272.

[21] Mosakowski, E., (1997), "Strategy making under causal ambiguity: conceptual issues and empirical evidence", Organization Science, Vol. 8, No.4, pp. 414-442.

[22] O'Gorman, C., \& Doran, R. (1999), "Mission statements in small and medium-sized business", Journal of Small Business Management, Vol. 37, No. 4, pp. 59-68.

[23] Posner, B.G. (1985), "Real entrepreneurs don't plan", Inc, Vol. 7, No. 11 , pp. 129-32

[24] Schwenk, C.B., Shrader C.B., (1993), "Effects of formal strategic planning on financial performance in small firms: a metaanalysis", Entrepreneurship Theory and Practice, Vol. 17, No. 3 , pp. 53-64.

[25] Sarason, Y., Tegarden, L.F., (2003), "The erosion of the competitive advantage of strategic planning: a configuration theory and resource based view", Journal of Business and Management, Vol. 9, No. 1, pp. 1-20.

[26] Wiltbank, R., Dew, N., Read, S., Sarasvathy, S.D., (2006), "What to do next? The case for non-predictive strategy", Strategic Management Journal, Vol. 27, No. 10, pp. 981-998.

\title{
Istraživanje prakse poslovnog planiranja MSP-a zemlje u razvoju
}

\author{
Andrea Ivanisević, Alpar Lošonc, Slobodan Morača, Petar Vrgović, Ivana Katić
}

Primljen (28.12.2018.); Recenziran (21.01.2019.); Prihvaćen (20.02.2019.)

\begin{abstract}
Abstrakt
U radu se analizira stanje u oblasti poslovnog planiranja u malim i srednjim preduzećima u Srbiji, kao i stavovi menadžera prema sistemu poslovnog planiranja koji se uvodi u preduzeće. Cilj ovog rada je da utvrdi da li preduzeća koja su uvela takav sistem planiranja imaju to kao formalni proces, i ako to čine, da li se sprovođenje prati tokom godine, a takođe, da li se preduzimaju sve mere u slučaju pogoršanja na poslovnom planu i lošim poslovnim rezultatima, kako bi se postiglo racionalnije poslovanje, odnosno da li se adekvatan monitoring primjenjuje u skladu sa sistemom povratnih informacija?
\end{abstract}

Ključne reči: poslovni plan, kontrola, okruženje, neizvesnost, povratne informacije. 